\title{
Evaluation of Animal Dungs and Organomineral Fertilizer for the Control of Meloidogyne incognita on Sweet Potato
}

\author{
Oluremi Solomon Osunlola ${ }^{1}$ and Bamidele Fawole ${ }^{2}$ \\ ${ }^{1}$ Department of Crop Production, Kwara State University, Malete, PMB 1530, Ilorin, Nigeria \\ ${ }^{2}$ Department of Crop Protection and Environmental Biology, University of Ibadan, Ibadan, Nigeria \\ Correspondence should be addressed to Oluremi Solomon Osunlola; remiosunlola@gmail.com
}

Received 28 September 2015; Revised 3 December 2015; Accepted 10 December 2015

Academic Editor: David Clay

Copyright ( 92015 O. S. Osunlola and B. Fawole. This is an open access article distributed under the Creative Commons Attribution License, which permits unrestricted use, distribution, and reproduction in any medium, provided the original work is properly cited.

\begin{abstract}
Root-knot nematode, Meloidogyne incognita, is an important animate pathogen causing major damage and severe reductions in the growth, yield, and quality of sweet potato. Nematicides are expensive and their application also causes environmental pollution. A field experiment was therefore conducted to evaluate the effectiveness of poultry dung (10 or $20 \mathrm{t} / \mathrm{ha})$, cow dung (10 or $20 \mathrm{t} / \mathrm{ha}$ ), horse dung (10 or $20 \mathrm{t} / \mathrm{ha}$ ), goat dung (10 or $20 \mathrm{t} / \mathrm{ha})$, organomineral fertilizer ( 2 or $4 \mathrm{t} / \mathrm{ha})$, and carbofuran ( $3 \mathrm{~kg}$ a.i/ha) in the management of $M$. incognita on sweet potato using a randomized complete block design. The unamended plots served as control. Data were analysed using ANOVA $(p \leq 0.05)$. All organic materials and carbofuran significantly $(p \leq 0.05)$ reduced nematode reproduction and root damage compared with control. Poultry dung (10 and $20 \mathrm{t} / \mathrm{ha}$ ) and carbofuran were, however, more efficient in nematode control than other organic materials. Sweet potato plants that were grown on soil treated with organomineral fertilizer had the highest mean number of vines and fresh shoot weight, while poultry dung improved sweet potato quality and yield. It is therefore recommended that the use of poultry dung be employed in combination with other nematode control strategies to achieve sustainable, economic, and environment-friendly nematode management.
\end{abstract}

\section{Introduction}

Sweet potato (Ipomoea batatas L. Lam) is a dicotyledonous crop that belongs to the family Convolvulaceae. It is the world's second most important root and tuber crop after potato [1]. Sweet potato is normally cultivated for its large, starchy, sweet-tasting tuber which is primarily used as food stuff and is often boiled, fried, roasted, baked, canned, or fermented for human consumption $[2,3]$. It is also used to produce flour for bread and pastry making [4]. Different kinds of products such as edible and fermentable syrups, industrial alcohol, dye, acetone, lactic acid, vinegar, yeast, pie fillings, purees, candied pieces, soufflés, and baby foods are made from sweet potato [5]. Sweet potato has also been used as a laxative and antidiabetic and in the treatment of low fever and skin diseases [5]. Root-knot disease caused by rootknot nematodes, Meloidogyne spp., is a well known disease of many tropical and subtropical crops. Meloidogyne incognita is the most important nematode pest of sweet potato which occurs in most sweet potato growing regions where it causes severe damage [6, 7]. Symptoms of $M$. incognita infection include patchiness in field, stunting, wilting, chlorosis, and galling of the root system. Galls are, however, not usually well-developed on tubers, but the obvious symptoms on tubers are longitudinal cracks and blister-like bumps [8]. $M$. incognita has been implicated in yield reduction of sweet potato by earlier workers. Losses between 20 and $83.2 \%$ have been reported by earlier workers [9-12]. Although the use of nematicides has been found to be effective for nematode control, due to high toxic residual effect of chemicals on environment, particularly on nontarget organisms [13], there is a need to develop alternative nematode control measures. Earlier workers have reported the effectiveness of different materials like plant manures, plant extracts, and animal manures in nematode management and consequent improved crop growth and yield [14-16].

The objective of this study was to evaluate poultry, cow, goat, and horse dungs and organomineral fertilizer in the management of $M$. incognita and assess their effects on the growth, yield, and quality of sweet potato in the field. 


\section{Materials and Methods}

The experiment was carried out in 2009 and 2010 cropping seasons on a piece of land that was naturally infested by Meloidogyne incognita in the Crop Garden of the Department of Crop Protection and Environmental Biology, University of Ibadan, Ibadan. Three months before the commencement of the experiment, the nematode was multiplied under Celosia argentea to augment the field population. The piece of land was divided into seven equal blocks and each block was further divided into twelve equal plots measuring $2.5 \times 2.5 \mathrm{~m}$ each. There was a spacing of $1 \mathrm{~m}$ between the blocks and $0.5 \mathrm{~m}$ between plots. Soil samples were collected in a zigzag manner from each plot four days before planting. Nematodes were extracted from the soil samples using the method of Whitehead and Hemming [17]. The root-knot nematode juveniles $\left(J_{2}\right)$ extracted were counted under a stereoscope after 48 hours in a counting dish. The animal dungs used in the study were collected from the Teaching and Research Farm of the University and were air dried for three weeks before use. Organomineral fertilizer was obtained from the Department of Agronomy, University of Ibadan, while carbofuran was purchased from an agrochemical shop in Ibadan. The plots were thereafter treated with air-dried poultry manure, goat manure, cow manure, and horse manure each at two rates: $10 \mathrm{t} / \mathrm{ha}$ and $20 \mathrm{t} / \mathrm{ha}$; organomineral fertilizer at two rates: $2 \mathrm{t}$ and $4 \mathrm{t} / \mathrm{ha}$; carbofuran at $3 \mathrm{~kg}$ a.i/ha, and untreated plots served as control. Three weeks after the application of the organic materials and chemical, vine cuttings of $M$. incognita susceptible sweet potato cultivar (CV TIS 4400-2) [18] were planted to each plot. The experiment was laid out in a randomized complete block design with twelve treatments in seven replicates.

The plants were rain fed as the experiment was carried out during the raining seasons. The experimental plot was kept weed-free by regular hoeing. The plants were harvested five months after planting and the root systems were rated for root damage (gall index) on a scale of $0-5$ where 0 equals no gall; 1 equals $1-20 \%$ of the root system galled; 2 equals $21-$ $40 \%$ of the root system galled; 3 equals $41-60 \%$ of the root system galled; 4 equals $61-80 \%$ of the root system galled; and 5 equals $81-100 \%$ of the root system galled [19]. Similarly, data were taken on number of vines per plant, fresh shoot weights $(\mathrm{g})$, fresh root weights $(\mathrm{g})$, number of tubers, and tuber weight $(\mathrm{g})$. The dry shoot and root weights $(\mathrm{g})$ were also taken and this was accomplished by transferring them in well labeled envelopes into the oven that was set at $80^{\circ} \mathrm{C}$ for three days. Swollen root quality which was rated on a scale of $0-5$ where 0 equals completely smooth tubers/no cracks; 1 equals $1-20 \%$ of the tubers skin rough/cracked; 2 equals $21-40 \%$ of the tubers skin rough/cracked; 3 equals $41-60 \%$ of the tuber skin rough/cracked; 4 equals $61-80 \%$ of the tuber skin rough/cracked; and 5 equals $81-100 \%$ of the tuber skin rough/cracked was also taken. The root and soil nematode populations were also determined with the methods of Hussey and Barker [20] and Whitehead and Hemming [17], respectively. All data were processed with Analysis of Variance (ANOVA) using Statistics Analysis Software (SAS) [21] and the means were separated using
Duncan's Multiple Range Test at a probability level of 5\%. The second trial was carried out in the adjacent piece of land in the crop garden during the 2010 cropping season as described for the first trial above.

\section{Result}

The least mean gall index (root damage) came from the carbofuran-treated soil and was followed by the values from poultry manure (20 and $10 \mathrm{t} / \mathrm{ha}$ ) amended soil in both trials (Table 1). The highest significant mean gall index was obtained from the plants grown on unamended soil (Table 1). Carbofuran-treated soil had the least significant mean soil nematode population $\left(J_{2}\right)$ which was not significantly lower than the values obtained from plants treated with poultry manure (10 and $20 \mathrm{t} / \mathrm{ha}$ ) (Table 1 ). The highest significant mean number of second stage $\left(J_{2}\right)$ number was obtained from unamended soil. The least mean nematode egg population was recorded from plants raised in carbofuran-treated soil and this did not differ significantly from the values obtained from the plants treated with both levels of poultry manure (Table 1). The plants from unamended soil produced the highest significant mean nematode egg population (Table 1).

The plants grown on organomineral fertilizer ( $4 \mathrm{t} / \mathrm{ha}$ ) produced the highest mean number of vines which did not differ significantly from the values obtained from other organic materials. The least significant value came from the unamended soil (Table 2). The highest mean fresh and dry shoot weights were recorded from the plants grown on organomineral fertilizer ( $4 \mathrm{t} / \mathrm{ha}$ ) treated soil. They were, however, not significantly higher than the values obtained from other treatments except those from amended soil which produced the lowest values (Table 2). The highest mean fresh and dry root weights came from sweet potato plants grown on poultry manure $(20 \mathrm{t} / \mathrm{ha}$ ) treated soil followed by values from those plants grown on organomineral fertilizer ( $4 \mathrm{t} / \mathrm{ha})$. The unamended soil produced the plants with the least mean fresh and dry root weights (Table 2). The highest mean number of swollen roots and swollen root weight were produced by the plants from poultry dung (20 t/ha) amended soil. It was not significantly higher than the values from poultry dung treated plants (10 t/ha) and other treatments except the unamended plots which had the least value (Table 3 ). The lowest mean swollen root damage index came from carbofuran-treated soil which was not significantly lower than the value obtained from poultry manure (10 and $20 \mathrm{t} / \mathrm{ha}$ ) amended soil (Table 3 ). The highest significant mean value was recorded from plants grown on unamended soil (Table 3 ).

\section{Discussion}

Results from this experiment showed that various animal dungs, organic fertilizer, and carbofuran effectively reduced sweet potato root damage (galls) and nematode reproduction compared with control (unamended soil). Carbofuran and poultry dung were however superior to other treatments. This is consistent with the findings of Babatola, Oduor-Owino, Orisajo et al., Daramola et al., and Shiferaw et al. [14, 15, 2224] who reported the effectiveness of poultry manure and 
TABLE 1: Comparative effects of different organic materials and carbofuran on the means of gall index and Meloidogyne incognita reproduction on sweet potato.

\begin{tabular}{|c|c|c|c|c|c|c|}
\hline \multirow{2}{*}{ Treatments } & \multicolumn{2}{|c|}{${ }^{*}$ Gall index } & \multicolumn{2}{|c|}{$J_{2}$ population in $200 \mathrm{~mL}$ soil $(\times 500)$} & \multicolumn{2}{|c|}{ Root egg population $/ 100 \mathrm{~g}$ root $(\times 1000)$} \\
\hline & 1st trial & 2nd trial & 1st trial & 2nd trial & 1st trial & 2nd trial \\
\hline Poultry manure $10 \mathrm{t} / \mathrm{ha}$ & $1.6 \mathrm{e}^{* *}$ & $1.6 \mathrm{de}$ & $1.9 \mathrm{bcd}$ & $2.0 \mathrm{bc}$ & $39.9 \mathrm{cde}$ & 41.9def \\
\hline Poultry manure $20 \mathrm{t} / \mathrm{ha}$ & $1.0 \mathrm{f}$ & 1.1de & $1.6 \mathrm{~cd}$ & $1.7 \mathrm{~cd}$ & $30.9 \mathrm{de}$ & $30.7 \mathrm{ef}$ \\
\hline Goat manure $10 \mathrm{t} / \mathrm{ha}$ & $1.9 \mathrm{cde}$ & $1.9 \mathrm{bcd}$ & $2.6 \mathrm{bc}$ & $3.0 \mathrm{~b}$ & $51.7 \mathrm{bcd}$ & $53.1 \mathrm{~cd}$ \\
\hline Goat manure $20 \mathrm{t} / \mathrm{ha}$ & $1.7 \mathrm{de}$ & $1.8 \mathrm{~cd}$ & $2.3 \mathrm{bcd}$ & $2.4 \mathrm{bc}$ & $41.6 \mathrm{cde}$ & 49.6de \\
\hline Cow manure $10 \mathrm{t} / \mathrm{ha}$ & $2.3 \mathrm{bc}$ & $2.6 \mathrm{bc}$ & $3.3 \mathrm{~b}$ & $3.3 \mathrm{~b}$ & $58.0 \mathrm{bc}$ & $57.3 \mathrm{bc}$ \\
\hline Cow manure 20 t/ha & $1.7 \mathrm{de}$ & $1.7 \mathrm{de}$ & $3.0 \mathrm{bc}$ & $3.1 \mathrm{~b}$ & $44.3 \mathrm{~cd}$ & $51.9 \mathrm{~cd}$ \\
\hline Horse manure $10 \mathrm{t} / \mathrm{ha}$ & $2.7 \mathrm{~b}$ & $2.9 \mathrm{~b}$ & $3.4 \mathrm{~b}$ & $3.6 b$ & $68.3 b$ & $68.9 b$ \\
\hline Horse manure $20 \mathrm{t} / \mathrm{ha}$ & $2.0 \mathrm{cde}$ & $2.1 \mathrm{bcd}$ & $3.1 \mathrm{bc}$ & $3.4 \mathrm{~b}$ & $57.1 \mathrm{bc}$ & $55.4 \mathrm{bc}$ \\
\hline Organomineral fertilizer $2 \mathrm{t} / \mathrm{ha}$ & $2.3 \mathrm{bc}$ & $2.5 \mathrm{bc}$ & $3.4 \mathrm{~b}$ & $3.4 \mathrm{~b}$ & $68.6 b$ & $70.0 \mathrm{~b}$ \\
\hline Organomineral fertilizer $4 \mathrm{t} / \mathrm{ha}$ & $2.1 \mathrm{~cd}$ & $2.1 \mathrm{bcd}$ & $3.0 \mathrm{bc}$ & $3.1 \mathrm{~b}$ & $57.3 \mathrm{bc}$ & $56.7 \mathrm{bc}$ \\
\hline Carbofuran $3 \mathrm{kgai} / \mathrm{ha}$ & $0.4 \mathrm{f}$ & $0.5 \mathrm{e}$ & $0.7 \mathrm{~d}$ & $0.8 \mathrm{~d}$ & $20.1 \mathrm{e}$ & $16.3 \mathrm{f}$ \\
\hline Unamended soil & $4.0 \mathrm{a}$ & $4.0 \mathrm{a}$ & $13.0 \mathrm{a}$ & $13.4 \mathrm{a}$ & $199.9 \mathrm{a}$ & $207.3 \mathrm{a}$ \\
\hline
\end{tabular}

${ }^{*} 0$ equals no gall; 1 equals $1-20 \%$ of the root system galled; 2 equals $21-40 \%$ of the root system galled; 3 equals $41-60 \%$ of the root system galled; 4 equals $61-$ $80 \%$ of the root system galled; and 5 equals $81-100 \%$ of the root system galled. ${ }^{* *}$ Means followed by the same letter in the same column are not significantly different according to Duncan's Multiple Range Test $(P<0.05)$. Each value is a mean of seven replicates.

TABLE 2: Effect of various organic materials and carbofuran on the growth of sweet potato.

\begin{tabular}{|c|c|c|c|c|c|c|c|c|c|c|}
\hline \multirow{2}{*}{ Treatments } & \multicolumn{2}{|c|}{ Number of vines } & \multicolumn{2}{|c|}{ Fresh shoot weight (g) } & \multicolumn{2}{|c|}{ Dry shoot weight (g) } & \multicolumn{2}{|c|}{ Fresh root weight $(\mathrm{g})$} & \multicolumn{2}{|c|}{ Dry root weight (g) } \\
\hline & 1st trial & 2nd trial & 1st trial & 2nd trial & 1st trial & 2nd trial & 1st trial & 2nd trial & 1st trial & 2nd trial \\
\hline Poultry manure $10 \mathrm{t} / \mathrm{ha}$ & $28.4 a^{*}$ & $29.0 \mathrm{ab}$ & $412.2 \mathrm{a}$ & $413.4 \mathrm{abc}$ & $115.3 \mathrm{ab}$ & $117.3 \mathrm{abc}$ & $110.2 \mathrm{ab}$ & $104.6 \mathrm{abc}$ & $11.9 \mathrm{bc}$ & $13.3 c$ \\
\hline Poultry manure $20 \mathrm{t} / \mathrm{ha}$ & $30.1 \mathrm{a}$ & $30.9 \mathrm{ab}$ & $439.4 \mathrm{a}$ & $415.3 \mathrm{ab}$ & $122.9 \mathrm{a}$ & $126.0 \mathrm{ab}$ & $119.8 \mathrm{a}$ & $111.7 \mathrm{a}$ & $14.7 \mathrm{a}$ & 15.1ab \\
\hline Goat manure $10 \mathrm{t} / \mathrm{ha}$ & $28.0 \mathrm{a}$ & $28.4 \mathrm{ab}$ & $411.6 \mathrm{a}$ & $398.0 \mathrm{bc}$ & $113.9 \mathrm{ab}$ & $112.0 \mathrm{bcd}$ & $103.1 \mathrm{cde}$ & $101.4 \mathrm{~cd}$ & $13.4 \mathrm{ab}$ & $13.6 \mathrm{abc}$ \\
\hline Goat manure $20 \mathrm{t} / \mathrm{ha}$ & $28.6 \mathrm{a}$ & $30.0 \mathrm{ab}$ & $410.6 \mathrm{a}$ & $386.1 \mathrm{bc}$ & $115.6 \mathrm{ab}$ & $120.3 \mathrm{ab}$ & 118.lab & 111.1ab & $14.3 \mathrm{a}$ & $14.4 \mathrm{abc}$ \\
\hline Cow manure $10 \mathrm{t} / \mathrm{ha}$ & $27.0 \mathrm{a}$ & $28.3 \mathrm{ab}$ & $372.9 \mathrm{a}$ & $370.0 \mathrm{bcd}$ & $110.4 \mathrm{ab}$ & $109.9 \mathrm{~cd}$ & 98.0def & $96.7 \mathrm{de}$ & $10.9 \mathrm{~cd}$ & $9.8 \mathrm{de}$ \\
\hline Cow manure $20 \mathrm{t} / \mathrm{ha}$ & $28.3 \mathrm{a}$ & $28.6 \mathrm{ab}$ & $409.9 \mathrm{a}$ & $385.4 \mathrm{bc}$ & $114.2 \mathrm{ab}$ & $115.9 \mathrm{bcd}$ & $108.7 \mathrm{abcd}$ & $103.3 \mathrm{bcd}$ & $11.6 \mathrm{bcd}$ & $11.4 \mathrm{~d}$ \\
\hline Horse manure $10 \mathrm{t} / \mathrm{ha}$ & $256 a$ & $24.7 \mathrm{abc}$ & $380.7 \mathrm{a}$ & $368.6 \mathrm{bcd}$ & $102.6 \mathrm{ab}$ & $105.6 \mathrm{cde}$ & $96.8 \mathrm{ef}$ & 95.7de & $11.4 \mathrm{bcd}$ & $11.1 \mathrm{~d}$ \\
\hline Horse manure $20 \mathrm{t} / \mathrm{ha}$ & $27.7 \mathrm{a}$ & $26.6 \mathrm{abc}$ & $387.9 \mathrm{a}$ & $376.0 \mathrm{bc}$ & $112.9 \mathrm{ab}$ & $111.0 \mathrm{bcd}$ & $100.4 \mathrm{cde}$ & 97.4de & $11.1 \mathrm{~cd}$ & $10.3 \mathrm{~d}$ \\
\hline Organomineral fertilizer $2 \mathrm{t} / \mathrm{ha}$ & $26.1 \mathrm{a}$ & $25.7 \mathrm{abc}$ & $404.9 \mathrm{a}$ & $383.3 \mathrm{bc}$ & $115.6 \mathrm{ab}$ & $120.7 \mathrm{ab}$ & $108.5 \mathrm{bcd}$ & $102.3 \mathrm{bcd}$ & $11.3 \mathrm{bcd}$ & $10.9 d$ \\
\hline Organomineral fertilizer $4 \mathrm{t} / \mathrm{ha}$ & $30.3 \mathrm{a}$ & $32.7 \mathrm{a}$ & $469.6 \mathrm{a}$ & $422.4 \mathrm{a}$ & $127.5 \mathrm{a}$ & $128.6 \mathrm{a}$ & $110.2 \mathrm{abc}$ & $104.3 \mathrm{abc}$ & $14.7 \mathrm{a}$ & $15.3 \mathrm{a}$ \\
\hline Carbofuran $3 \mathrm{kgai} / \mathrm{ha}$ & $25.7 \mathrm{a}$ & $27.0 \mathrm{abc}$ & $372.9 \mathrm{a}$ & $369.4 \mathrm{bcd}$ & $105.6 \mathrm{ab}$ & $109.3 \mathrm{~cd}$ & $106.3 \mathrm{cde}$ & $101.7 \mathrm{~cd}$ & $11.1 \mathrm{~cd}$ & $10.4 \mathrm{~d}$ \\
\hline Unamended soil & 23.1a & $18.1 \mathrm{c}$ & $328.2 \mathrm{a}$ & $312.7 \mathrm{~d}$ & $90.7 \mathrm{~b}$ & $90.7 \mathrm{e}$ & 87.1ef & $86.9 \mathrm{ef}$ & $9.5 \mathrm{~d}$ & $8.2 \mathrm{e}$ \\
\hline
\end{tabular}

${ }^{*}$ Means followed by the same letter in the same column are not significantly different according to Duncan's Multiple Range Test $(P<0.05)$. Each value is a mean of seven replicates.

carbofuran and rapeseed cake in curtailing the menace of plant-parasitic nematodes on tomato, cacao seedlings, and pineapple. Poultry dung extract was found to cause $100 \%$ mortality of Rotylenchulus reniformis on cowpea compared with other dungs in a laboratory trial [25]. Reduction in root damage and nematode reproduction could be due to a number of factors. For example, poultry manure is reputed to have high nitrogen content [25] and the ammonification of nitrogen compound was reported to be nematicidal [26]. The suppression of nematode population has been attributed to the low $\mathrm{C}: \mathrm{N}$ ratio of the poultry litter used in their study [14]. It has also been reported that soil amendment with a low $\mathrm{C}: \mathrm{N}$ ratio (less than $20: 1$ ) substrate gave rise to abundance of enrichment-opportunistic antagonistic microbes and rapid mineralization of $\mathrm{N}$ and absorption by plant roots [2729]. Three nematophagous fungi species were isolated from poultry, horse, pig, and carabao dungs [25]. Poultry manure treated soil had been earlier reported to contain the highest percentage of nematophagous fungi compared with cow and horse manures [30]. The suppression of nematode population could also be due to changes in soil physical and chemical conditions which may have altered the plant/nematode relationships resulting in the plant being more resistant to the development of nematode within its roots. All organic materials also improved sweet potato growth and yield compared with control. Increase in top weights of sweet potato and cassava grown on nematode-infested soil treated with nematicide and poultry manures was also reported by 
TABLE 3: Effect of various organic materials on tuber yield and quality.

\begin{tabular}{|c|c|c|c|c|c|c|}
\hline \multirow{2}{*}{ Treatments } & \multicolumn{2}{|c|}{ Number of swollen roots } & \multicolumn{2}{|c|}{ Swollen root weight (g) } & \multicolumn{2}{|c|}{ Swollen root quality ${ }^{* *}$} \\
\hline & 1st trial & 2nd trial & 1st trial & 2nd trial & 1st trial & 2nd trial \\
\hline Poultry manure $10 \mathrm{t} / \mathrm{ha}$ & $3.4 \mathrm{ab}^{*}$ & $3.7 \mathrm{ab}$ & $329.5 \mathrm{ab}$ & $387.7 \mathrm{a}$ & $1.3 \mathrm{~cd}$ & $1.4 \mathrm{de}$ \\
\hline Poultry manure $20 \mathrm{t} / \mathrm{ha}$ & $4.0 \mathrm{a}$ & $4.2 \mathrm{a}$ & $471.5 \mathrm{a}$ & 446.1a & $0.7 \mathrm{de}$ & $0.6 \mathrm{f}$ \\
\hline Goat manure $10 \mathrm{t} / \mathrm{ha}$ & $2.6 \mathrm{ab}$ & $2.6 \mathrm{bc}$ & 301.0ab & $309.7 \mathrm{ab}$ & $1.7 \mathrm{bc}$ & $1.7 \mathrm{cde}$ \\
\hline Goat manure $20 \mathrm{t} / \mathrm{ha}$ & $3.3 \mathrm{ab}$ & $3.1 \mathrm{ab}$ & $439.6 a$ & 437.1a & $1.3 \mathrm{~cd}$ & $1.4 \mathrm{de}$ \\
\hline Cow manure $10 \mathrm{t} / \mathrm{ha}$ & $2.7 \mathrm{ab}$ & $2.9 \mathrm{bc}$ & $290.8 \mathrm{ab}$ & 299.9ab & $1.9 \mathrm{bc}$ & $1.9 \mathrm{bcd}$ \\
\hline Cow manure $20 \mathrm{t} / \mathrm{ha}$ & $2.9 \mathrm{ab}$ & $2.9 \mathrm{bc}$ & $328.3 \mathrm{ab}$ & $371.3 \mathrm{a}$ & $1.7 \mathrm{bc}$ & $1.7 \mathrm{cde}$ \\
\hline Horse manure $10 \mathrm{t} / \mathrm{ha}$ & $2.4 \mathrm{ab}$ & $2.4 \mathrm{bc}$ & $260.0 \mathrm{ab}$ & $289.0 \mathrm{ab}$ & $2.3 \mathrm{ab}$ & $2.4 \mathrm{~b}$ \\
\hline Horse manure $20 \mathrm{t} / \mathrm{ha}$ & $2.7 \mathrm{ab}$ & $2.7 \mathrm{bc}$ & $312.2 \mathrm{ab}$ & $339.4 \mathrm{ab}$ & $2.1 \mathrm{ab}$ & $2.1 \mathrm{bc}$ \\
\hline Organomineral Fertilizer $2 \mathrm{t} / \mathrm{ha}$ & $2.5 \mathrm{ab}$ & $2.4 \mathrm{bc}$ & $308.0 \mathrm{ab}$ & $327.0 \mathrm{ab}$ & 2.1ab & $2.1 \mathrm{bc}$ \\
\hline Organomineral fertilizer $4 \mathrm{t} / \mathrm{ha}$ & $3.4 \mathrm{ab}$ & $3.4 \mathrm{ab}$ & $384.1 \mathrm{ab}$ & $404.9 \mathrm{a}$ & 2.1ab & $2.0 \mathrm{bcd}$ \\
\hline Carbofuran $3 \mathrm{kgai} / \mathrm{ha}$ & $3.4 \mathrm{ab}$ & $3.1 \mathrm{ab}$ & $318.6 \mathrm{ab}$ & $351.0 \mathrm{ab}$ & $0.4 \mathrm{f}$ & $0.4 \mathrm{f}$ \\
\hline Unamended soil & $2.0 \mathrm{~b}$ & $1.9 \mathrm{c}$ & $218.0 \mathrm{~b}$ & $248.7 b$ & $3.6 \mathrm{a}$ & $3.4 \mathrm{a}$ \\
\hline
\end{tabular}

${ }^{*}$ Means followed by the same letters in the same column are not significantly different according to Duncan's Multiple Range Test $(P<0.05)$. ${ }^{* *} 0$ equals completely smooth tubers/no cracks; 1 equlas $1-20 \%$ of the tubers skin rough/cracked; 2 equals $21-40 \%$ of the tubers skin rough/cracked; 3 equals $41-60 \%$ of the tuber skin rough/cracked; 4 equals $61-80 \%$ of the tuber skin rough/cracked; and 5 equals $81-100 \%$ of the tuber skin rough/cracked. Each value is a mean of seven replicates.

[31]. Poultry manure-treated plants had higher top weight than carbofuran-treated plants. Soil amendment with poultry litter alone or in combination with carbofuran significantly increased the dry shoot weight and stem girth of cacao seedlings compared with control [14]. The improvement in the growth and yield of sweet potato could be due to fertility provided by various organic materials used [14, 22]. Poultry litter has been reported to contain significant quantities of $\mathrm{N}, \mathrm{P}, \mathrm{K}, \mathrm{Ca}, \mathrm{Mg}$, and micronutrients and can be used as a substitute for commercial fertilizers [32].

\section{Conclusion}

The results of this study showed that the application of poultry dung at $10 \mathrm{t} /$ ha compete favourably with carbofuran in terms of nematode population reduction. Aside from this, poultry manure also improved soil fertility, which enhanced the growth and yield of sweet potato better than carbofuran. Furthermore, the use of poultry manure for nematode control will help to a large extent to solve the problem associated with its disposal. Therefore, from economic, health and environmental considerations, the use of poultry dung in the control of root-knot nematode is recommended.

\section{Conflict of Interests}

The authors declare that there is no conflict of interests regarding the publication of this paper.

\section{References}

[1] J. M. Lenne, Diseases and Pests of Sweet Potato: South East Asia, the Pacific and East Africa, vol. 46 of Natural Resources Institute Bulletin, 1991.

[2] I. C. Onwueme and T. D. Sinha, "Sweetpotato," in Field Crop Production in Tropical Africa, pp. 267-273, CTA, Ede, The Netherlands, 1991.
[3] S. O. Odebode, Sweetpotato (Ipomoea batatas (L) Lam) Utilization Manual (A Recipe Book), Codat Publications, 2008.

[4] O. Odebode, "Acceptability of sweetpotato 'Spari' and its potentials for enhancing food security and economic empowerment of rural women in South-Western Nigeria," The Nigerian Journal of Rural Sociology, no. 1-2, pp. 104-112, 2004.

[5] S. P. Ghosh, T. Ramanujam, J. S. Jos, N. Moorthy, and R. G. Nair, Tuber Crops, Mohan Primlani for Oxford and IBH Publishing Company, New Delhi, India, 1988.

[6] P. Jatala, "Important nematodes of Sweetpotatoes," in Improvement of Sweet Potato in East Africa. Report of the Workshop on Sweet Potato Improvement in Africa. September-Oct 1987, pp. 101-102, ILARAD, Nairobi, Kenya, 1988.

[7] P. Jatala, "Important nematode pest of sweetpotatoes and their management," in Improvement of Sweetpotato (Ipomoea batatas) in Asia. Report of the Workshop on Sweet Potato Improvement in Asia, Oct. 1988, pp. 213-218, International Potato Center, Trivandrum, India, 1989.

[8] C. A. Clark and J. W. Moyer, Compendium of Sweetpotato Diseases, American Phytopathological Society Press, 1988.

[9] R. M. Gapasin and B. B. Validez, "Pathogenicity of Meloidogyne spp and Rotylenchulus reniformis on sweetpotato," Annals of Tropical Research, vol. 1, pp. 20-25, 1979.

[10] R. L. Theberge, "Common African pests and diseases of cassava, yam, sweet potatoes and cocoyam," in IITA 1985, pp. 26-28, Balding and Mausel, Wisbech, UK, 1985.

[11] R. M. Gapasin, "Pre-and post-infectional resistance of sweetpotatoes to Meloidogyne incognita and javanica," Annals of Tropical Research, vol. 8, pp. 176-188, 1986.

[12] O. S. Osunlola and B. Fawole, "Pathogenicity of root-knot nematode (Meloidogyne incognita) on sweetpotato (Ipomoea batatas (L. Lam)," International Journal of Agronomy and Agricultural Research, vol. 6, no. 2, pp. 47-53, 2015.

[13] I. A. Anastasiadis, I. O. Giannakou, D. A. Prophetou-Athanasiadou, and S. R. Gowen, "The combined effect of the application of a biocontrol agent Paecilomyces lilacinus, with various practices for the control of root-knot nematodes," Crop Protection, vol. 27, no. 3-5, pp. 352-361, 2008. 
[14] S. B. Orisajo, S. O. Afolami, O. Fademi, and J. J. Atungu, "Effects of poultry litter and Carbofuran soil amendments on Meloidogyne incognita attacks on cacao," Journal of Applied Biosciences, vol. 7, pp. 214-221, 2008.

[15] F. Y. Daramola, S. O. Afolami, A. A. Idowu, and I. S. Odeyemi, "Effects of poultry manure and carbofuran soil amendments on soil nematode population and yield of pineapple," International Journal of AgriScience, vol. 3, no. 4, pp. 298-307, 2013.

[16] K. Pakeerathan, G. Mikunthan, and N. Tharshani, "Eco-friendly management of root-knot nematode Meloidogyne incognita (Kofoid and White) chiwood using different green leaf manures on tomato under field conditions," American-Eurasian Journal of Agricultural \& Environmental Sciences, vol. 6, no. 5, pp. 494497, 2009.

[17] A. G. Whitehead and J. R. Hemming, "A comparison of some quantitative methods of extracting small vermiform nematodes from soil," Annals of Applied Biology, vol. 55, no. 1, pp. 25-38, 1965.

[18] O. S. Osunlola and B. Fawole, "Screening of sweetpotato cultivars for resistance to Meloidogyne incognita Race 2 in Ibadan, Nigeria," in Proceedings of the 6th Triennial Congress of the African Potato Association, A. Hanafi, Ed., pp. 258-265, Agadir, Morocco, April 2004.

[19] B. Fawole and O. S. Osunlola, "Comparative efficiency of thermotherapy and chemotherapy on control of root-knot nematodes, Meloidogyne spp., in yam tubers," African Journal of Root and Tuber Crops, vol. 3, no. 2, pp. 38-40, 1999.

[20] R. S. Hussey and K. R. Barker, "A comparison of methods of collecting inocula for Meloidogyne spp. including a new technique," Plant Disease Reporter, vol. 57, pp. 1025-1028, 1973.

[21] SAS Institute, SAS User's Guide: Statistics, Version 8.0e, SAS Institute, Cary, NC, USA, 1999.

[22] J. O. Babatola, "Effects of some organic manures on nematodes in Tomato cultivation," Pakistan Journal of Nematology, vol. 7, no. 1, pp. 39-46, 1989.

[23] P. Oduor-Owino, "Integrated management of root-knot nematodes using agrochemicals, organic matter and the antagonistic fungus, Paecilomyces lilacinus in natural field soil," Nematologia Mediterranea, vol. 31, no. 1, pp. 121-12, 2003.

[24] T. Shiferaw, N. Dechassa, and P. K. Sakhuja, "Influence of poultry litter and rapeseed cake on infestation of Meloidogyne incognita on tomato in Dire Dawa, eastern Ethiopia," Pakistan Journal of Nematology, vol. 32, no. 1, pp. 67-72, 2014.

[25] M. B. Castillo, "Some studies on the use of organic soil amendments for nematode control," Philippine Agricultural Scientist, vol. 68, pp. 76-93, 1985.

[26] J. T. Walker, "Populations of Pratylenchus penetrans relative to decomposing nitrogenous soil amendments," Journal of Nematology, vol. 1, pp. 260-264, 1971.

[27] H. Ferris and M. M. Matute, "Structural and functional succession in the nematode fauna of a soil food web," Applied Soil Ecology, vol. 23, no. 2, pp. 93-110, 2003.

[28] K.-H. Wang, R. McSorley, A. J. Marshall, and R. N. Gallaher, "Nematode community changes associated with decomposition of Crotalaria juncea amendment in litterbags," Applied Soil Ecology, vol. 27, no. 1, pp. 31-45, 2004.

[29] L. E. Powers and R. Mcsorley, Ecological Principles of Agriculture, Delmar Thompson Learning, Albany, NY, USA, 2000.

[30] T. T. Reyes and R. G. Davide, "Fungi for biological control of plant parasitic nematodes," NSDB Technical Bulletin 3, 1975.
[31] R. M. Gapasin, "Control of M. incognita and Rotylenchulus reniformis and its effects on the yield of sweet potatoes and cassava," Annals of Tropical Research, vol. 3, no. 2, pp. 92-100, 1981.

[32] J. T. Sims and D. C. Wolf, "Poultry waste management. Agricultural and Environmental issues," Advances in Agronomy, vol. 52, pp. 1-83, 1994. 


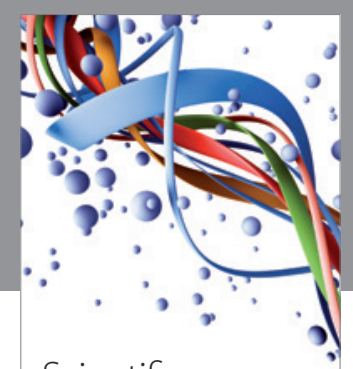

Scientifica
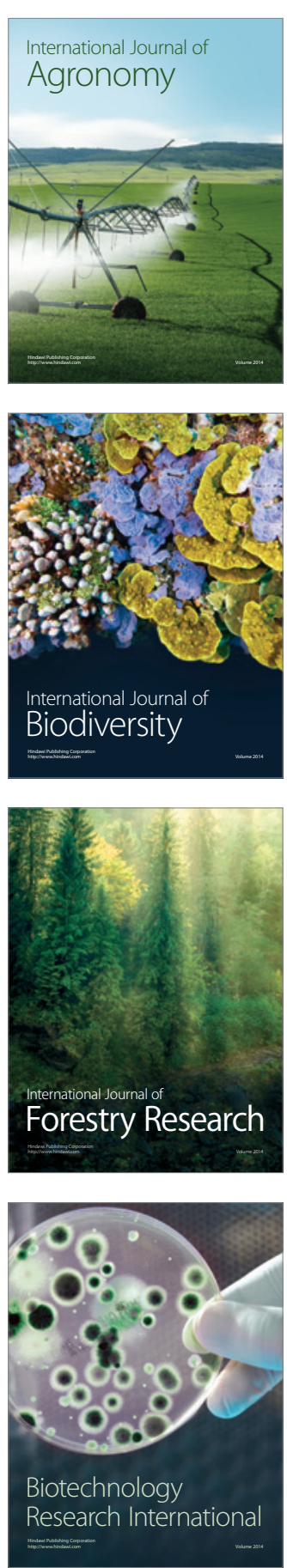
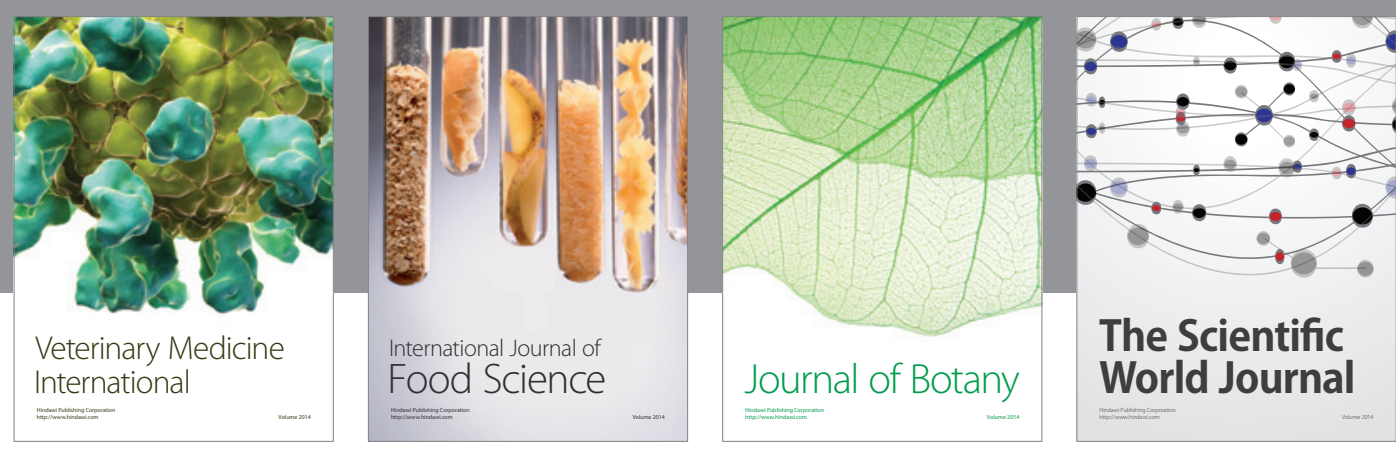

The Scientific World Journal
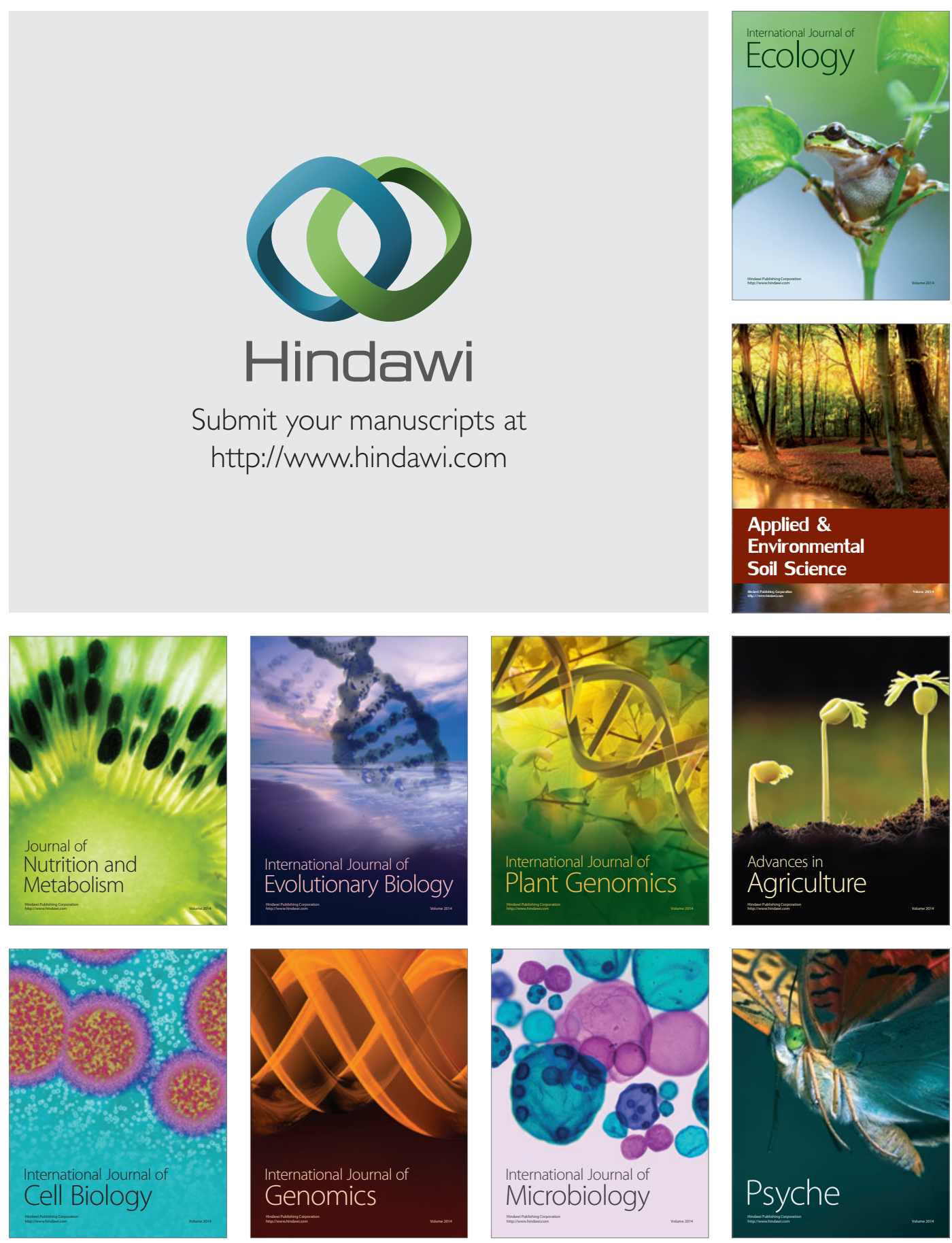